\section{Accounting Theory}

Por Eldon S. Hendriksen. Homewood, Illinois, Richard D. Irwin, Inc., 1977. 636 p.

A segunda edição deste livro, de 1970, já havia sido completamente modificada em relaçã் à primeira, de 1965, graças à contribuição do Prof. Roland F. Salmonson, da Michigan State University, conforme o próprio autor dizia no prefácio e também o resenhista teve oportunidade de sentir na própria carne, ao fazer, em 1968, um curso de teoria contábil com o referido mestre.

Sem dúvida alguma, a obra de Hendriksen, considerada desde sua primeira edição como uma das melhores sobre o assunto, nesta terceira edição - em que o Prof. Robert N. Anthony da Harvard University colabora com vários comentários - completa e inteiramente alterada, modificada ainda para melhor e atualizada, pode agora ser qualificada como a meIhor obra existente no momento sobre a teoria contábil.

O autor, nos 19 capítulos de seu livro : trata da matéria em estudo dentro de três niveis, a saber: o nivel estrutural lou sintáticol, que inclui as relações entre le dentro de) os sistemas proceduais e relatórios financeiros; o nivel interpretativo lou semânticol, ou seja, as relações de descrições e mensurações dos fenômenos do mundo real; e o nivel comportamental (behavioral (eve/), isto é, as reações de todos os usuários - tanto individuaimente quanto no mercado de capitais - das informações contábeis.

Com isto, o autor, de certo mo do, dificulta a compreensão de um ou outro capítulo, principalmente quando se faz uma leitura rápida; todavia, ao se ler com mais calma e atenção o capítulo que pode ter deixado dúvidas, percebé-se que a abordagem nos três niveis mencionados permite um entendimento muito melhor do assunto e, principalmente, o porquê disto ou daqui10.

Esta terceira edição está, conforme dito anteriormente, bastante atualizada, inclusive de acordo com os desenvolvimentos mais recentes de teoria financeira, como, por exemplo, a hipótese de mercados eficientes e a portfolio theory, bem como, com os últimos estudos publicados pela FASB (Financial Accounting Standards Boards), sucessora da APB (ACcounting Princibles Board), famosa pelos seus Opinions, Statements e Accounting research butletins, que, por sua vez, foi a sucessora do Committee on AccoGting Procedure, órgão da AICPA (American Institute of Certified Public Accountants); sendo a FASB, no momento, financiada em seus estudos e publicações não só pelo AlCPA, como também pelas grandes firmas de auditoria que operam nos EUA e pelas sociedades anônimas que são afiliadas ao Financial Executive Institute. Além de citar vários trabalhos de outros órgãos norte-americanos, como a Securities, and Exchange Comission (mais ou menos equivalente à nossa recém-criada Comissão de Valores Imobiliários). The Cost Accouting Standards Board. The American Accounting Association. The National Association of Accountants. The Financial Execu tives Institute etc., baseia-se Hendriksen em inúmeras publicações de órgãos de outros países, como - Institutel of Chartered Accountants in England and Wales, O Canadian Institute of Chartered Accountants, o Institute of Chartered Accountants in Australia, o Aus tralian Society of Accountants etc. e em duas organizações internacionais: a IASC IInternational Accounting Standards Committel e O ICCAP International Coordination Committee for the Accountancy Professionl, o que faz que o livro sirva não só a usuários dos EUA, como também aos de outras nações.

Exemplo típico da última afirmativa do parágrafo anterior é o capitulo sete, Financial reporting and price changes, onde o Brasil é citado, entre outros cinco países, no que concerne ao índice de preço dos consumidores (p. 212 , tabela 1), como a problemática pode ser discutida e, quiçá, resolvida, a questão da correção monetária (indexation) etc.

Em todos os 19 capítulos, Hendriksen discute os assuntos expostos mostrando as vantagens e desvantagens das várias escolas e/ou correntes de pensamento, sem tomar partido em favor desta ou daquela - coloca-se sempre que possivel, em posição de neutralidade. É interessante notar que o autor, freqüentemente, ao fazer uma afirmativa, utiliza logo em seguida as palavras but ou however, que são as duas palavras mais encontradas no livro inteiro e, além disso, conforme ele mesmo afirma no prefácio, ao final de cada capítulo existe referência a uma série de lei.turas que irão muitas vezes contra as idéias expostas no texto, o que nos comprova ser esta uma obra de verdadeiro cientista, que abre horizontes para o leitor.

Nenhum contabilista e mesmo financista pode deixar de conhecer com todos os detalhes este livro e ler pelo menos alguns dos artigos recomendados, os quais, repito, não necessariamente estão de acordo com as idéias de Hendriksen.

Assim, por exemplo, como pode um estudioso ou um profissional do campo de finanças tentar fazer uma análise da Demonstração de resultados (conhecida antigamente, e ainda utilizada na vida prática, como demonstração de lucros e perdas), sem ter conhecimento do conteúdo do capítulo cinco income concepts for financial reporting? Quantos financistas (e até contabilistas) estão a par da idéia de que os algarismos que a contabilidade mostra como sendo o lu- 
cro são tão bons quanto o bom senso da pessoa que os utiliza? Ou, então, quantos estão a par de que, ao usar informações contábeis (sobretudo no caso brasileiro, com o problema inflacionário crônico, em maior ou menor escala anual), expressas em rigidos termos de aritmética 10 balanço bate até o últumo centavol, tendem a acreditar nelas sem nenhuma divergência? Aliás, já em 1949, R. A. Foulke advertia sobre isto ao afirmar que: "O lucro líquido contábil, embora determinado e expresso de acordo com a linguagem da mais exata de todas as ciências, que é a matemática, é, quando muito, um algarismo muito geral".

Finalmente, Hendriksen termina seu livro apresentando, em apêndi$c e$, questões selecionadas de exames para a obtenção do certificado de CPA (Certified Public Accountant), relacionando-as por assunto. Aliás, no final de cada um dos 19 capítulos, o autor relaciona os assuntos ali tratados e, como todo bom livro norte-americano, apresenta, no final, ótimos índices analítico e onomástico, que muito facilitam ao leitor o manuseio desta verdadeira obra-prima.

Ivan Pinto Dias
Administração do tráfego telefônico, teoria e aplicação

Por Hildebrando Rebello da Silva. Livros Técnicos e Científicos.

Já é famosa, entre os usuários de computadores, a linguagem hermética e antididática dos manuais editados pelos fabricantes. De fato, sempre que um fabricante de computador lança um novo produto, quer de hardware, quer do software, o número de livros que reinterpretam os manuais, de maneira mais didática, com exemplos apropriados e tornando as novas ferramentas úteis para os profissionais é muito grande. E dentro desta analogia que vejo o livro $A d$ ministração do tráfego telefônico.

Num nivel mais elevado, o texto deveria empregar teoria das filas e todo o seu ferramental estatístico. Neste caso, exigir-se-ia do seu público leitor uma razoável sofisticação teórica. Este seria o nível no qual se decidem os objetivos a serem atingidos, definem-se prioridades, contrapõem-se custos sociais de falta de desempentio aos custos de investimentos e operacionais, montam-se os modelos teóricos e escolhem-se as variáveis aleatórias cujas propriedades estatísticas avaliam o desempenho do servico.

Administração do Tráfego Telefônico dirige-se a técnicos de nivel médio com boa formação. Não aparecem, neste livro, profundas considerações teóricas nem expressões matemáticas sofisticadas. Como bem explica o autor, ele se preocupa com um passo além de como medir, para entender o que está medindo e discutir ligeıramente por que medir, mas sem analisar a razão de um fabricante especificar como objetivo um certo tempo de três segundos e não outro valor qualquer.

O livro parece preencher muito bem a sua finalidade de texto para treinamento interno de técnicos nas companhias telefônicas. Entretanto, eu não o recomendaria para estudantes de engenharia, a não ser como ilustração do procedimento da rotina diária. De fato, espera-se de profissionais de nivel superior uma abordagem mais crítıca, criativa e inquisitiva, que o autor não pretende satisfazer.

A escolha das especificações técnicas de um determinado fabricante - com produtos largamente empregados entre nós - para servir de linha-mestra ao material a ser exposto foi muito apropriada.

Dada a opção brasileira para um - desenvolvimento pautado por uma maciça transferência de tecnologia, surge uma grande demanda de mão-de-obra técnica de grau médio para instalar e operar os equipamentos. O livra em apreço é certamente uma contrıbuição para a formação destes técnicos. Se a opção tecnológica tivesse sido outra - como o desenvolvimento de equipamentos nacionais, na sua concepcão - a formação requerida para técnicos de nível superior seria outra (certamente mais crlativa). Entretanto, a utilidade do livro para a formação de técnicos de nível médio não fica prejudicada.

Pierre J. Ehrlich 